\title{
Religious and scientific traditions in interpretation and "reading" of modern and canonical language of pedagogical text
}

\author{
Andrey V. Korzhuev - Tatiana Vlasova - Vladimir Sinyachkin - Vladimir V. \\ Vorozhikhin - Natalia E. Sudakova
}

DOI: 10.18355/XL.2020.13.03.08

\begin{abstract}
This article is aimed at identifying the possibility to solve the problem of adequate decoding of the pedagogy language in the format of correlation of religious and logical-and-semantic scientific traditions, which reveals a) similarity of scientific and religious interpretation of texts, on the basis of which pedagogy could adopt the experience of religious interpretative tradition; b) difference between these two types of interpretation, which can be the basis for their correct demarcation in the linguistic and cultural humanitarian field. The study of the problems mentioned has shown that there is a similarity between the classical scholarly humanitarian tradition of interpretation of texts and the religious tradition, which is reflected in the importance of the subject's appeal to the original or secondary text as an object of the cultural field and an intellectual phenomenon, archiving the findings of science or religious conceptualism. The similarity between the scientific and religious traditions of interpretation mentioned above refers to such forms of content interpretation as a) decoding and presentation of the semantics and stylistics of the text to the recipient's mind through a number of images and symbols that are clear to the recipient; b) decoding the essence of the metaphors, synecdoche, periphrasis and metonymy used by the author. The latter can be designated as a segment of experience, appropriate for adoption by scientific pedagogy from religious tradition.

Key words: hermeneutics, pedagogical text, religious and scientific tradition of interpretation and construing of the text, canonical text, adherents of a doctrine, interpretative field of the text
\end{abstract}

\section{Introduction}

Over the long period since the emergence of hermeneutics, such clichés as "cultural background, the spirit of the era", "penetration into the author's consciousness", "hidden meanings of the text", "the potency of the language interpreter" and the like have quite firmly entrenched in the glossaries of many humanitarian fields of knowledge. This may be fairly considered an indicator of the inclusion of more and more new objects and phenomena in the hermeneutic analysis as well as an increasingly wide range of links and relationships of dependence between them (Rusnakova et al., 2017). That said, the pivotal point, reflecting the extension of the subject of developing hermeneutics, is in many respects similar to the one designated by Friedrich David Schleiermacher, one of the founders of hermeneutics, - it is mainly the theory of rules and techniques of text interpretation and, of course, the problem of understanding, focused by the philosopher on rethinking the spiritual process occurring in the author of the text in the process of its creation. In this case, the interpreter acts as an intermediary between the reader and a particular cultural and historical tradition, in which he/she is somehow integrated. At the same time, according to H.G. Gadamer (1985), text is the "ultimate reality", which becomes the main subject of philosophy of linguistics, and the ability to feel the spirit that possessed the author behind the "letter of the text" and reveal the inner "hidden" meaning of the text (sometimes not even known to the author) is the main objective of the interpreter. 
On the other hand, all those who are concerned with the problems of text interpretation know as a gospel truth that the problem of interpretation of meanings and content is inherent in religious traditions; thus, the problem of understanding the meaning of the Holy Scripture, the principles of understanding sacred texts and traditions of their interpretation, biblical and Christian exegesis, Catholic interpretation, Buddhist hermeneutics of the text and a number of others are well known and described. This includes the specific type of Christian existentialist interpretation. The literature on the history of religion quite commonly uses clichés such as interpretation as a sacred ceremony and the experience of understanding the "other"; in religious systems of ancient societies, the discourse of interpretation was taught just like music, oratory, gymnastics, military science, etc. (Ceccarelli Lindenmeyer, 2012; Shulga, 2017). In this case, the interpreter was supposed to have the poetic talent and mystical experience, while the ability to think out and translate the thought of the Supreme Mind in the religious tradition was attributed to the interpreter as an element of secret divine knowledge. Proclaiming his/her truths, the interpreter demonstrated his/her creativity as the divine essence of his/her thinking and worldview. The affirmative form of the oracle's statements, their brevity, nonappeal to an explanation of a causal format of statements as well as their justification in the status of truths as argument assumed only oracle's authority. As time passed, hermeneutics confidently fitted in the religious tradition, and interpretation rose from simple understanding on the level close to literal format of textual forms interpretation to the status of a philosophical-and-methodological teaching. (Cf: Grassi, 2017)

Christian exegesis developed the theory and typology of the meaning contained in the content of the text, having divided the literal meaning into direct and figurative, gradually marking the deciphering of the allegorical meaning. This was a gradual process, which began with the first stage (up to 604 B.C.), continued with the second stage, taking us to the Council of Trent (1543 - 1563) and further developed after the Council of Trent (Dawes, 2004). The modern methodology of interpretation of the content of treasures and phenomena of religious culture is distinguished from the ancient one in a number of aspects: a) the modern interpreter primarily resorts not only to the context of a single phrase or line of a text, but to the entire literary and stylistic form of an article, essay or book, of course, taking into account the purpose of writing a specific text; b) the modern interpreter has an access to a huge array of historical knowledge and the philology of sacred languages, which has actively developed in the last hundred years.

In view of this reference, we can state that religious and scholarly humanitarian traditions show a significant degree of similarity in a number of aspects, and an attempt to oppose them today would be a manifestation of approaches that are to a certain extent vulgar and profane, ignoring the rapid change of social-andhumanitarian realities. Therefore, as a problem thesis, we put forward one that raises the question of the degree of expedient separation of interpretation of texts in the religious and scientific tradition, which today is the subject of a serious discussion in the humanities in general and in pedagogical studies, in particular. This is especially relevant today for pedagogical studies, because there is no doubt that Christian teachings are gradually returning to the scientific and practical landscape of pedagogy, filling the very content of pedagogy with moral categories, which cannot but influence, in one form or another, the process of pedagogical cognition, its methodological guidelines and regulations. Therefore, the identification and correct designation of the degree of similarity and difference of interpretations of pedagogical texts and interpretive procedures is a relevant research topic. 


\section{Literature Review}

The analysis of the problem stated in the title of the article inevitably makes us to turn to the philosophy of P. Ricoeur (2002), M. Heidegger (1993), and H.G. Gadamer (1985). In this analysis, we will primarily focus on the problem of the methodological status of hermeneutics, which is reflected in quite a polemical way in the works of Heidegger and P. Ricoeur (2002). In particular, Heidegger, reflecting on the links between hermeneutics and scientific methodologies, attempts to spread philosophical scholarly thinking onto those areas of meaning of language structures that other authors have avoided. The scholar emphasizes the validity of any statements about the "historical nature of being" within hermeneutics, while beyond this maxim Heidegger seriously criticizes the methodological status of hermeneutics. This criticism is heard, for example, in the statement that science is not able to present itself by means of its theory as an epistemological and metaconceptual structure (Heidegger, 1993). Therefore, Heidegger takes the problem of interpretation and decoding of the meanings of the humanities text language beyond the limits of the scientific method; he states that "understanding the essence of science shall not be within the scope of its tasks" (Heidegger, 1993). However, the following quote from Heidegger's work is quite interesting: although the sciences in their ways and by their tools cannot penetrate into the essence of science, yet every researcher and teacher engaged in a particular science, as rational beings, are able to move forward at different levels of understanding and support it (Heidegger, 1993). Here meta-scientific reflection, closely tied to the understanding of the essence of the ideas expressed in the scientific texts, refers to individual research strategies of the scientist that have a complex cognitive structure, however, it is not fully clear how hermeneutic and logic components are synthesized in these strategies when analyzing scientific texts.

Here it will make sense to turn to P. Ricoeur (2002), who criticizes Heidegger's positions. Declaring Heidegger's criticism of the methodological status of hermeneutics unreasonable (on the one hand, due to the impossibility to replace it with a special methodology of understanding, and on the other hand, due to the reproach for the fact that Heidegger rejects the traditional philosophical methodology with widely recognized canons of logical and substantive rigor). At the same time, Ricoeur himself asks the question, under what condition can the cognizing subject understand any given text, and what is "a being whose essence is to understand?" (Ricoeur, 2002). Despite that, Ricoeur fully recognizes Heidegger's ideas as a positive impulse, an incentive for scientific reflection on the content and meaning of the texts proposed by various authors. The importance of hermeneutics legacy for the philosophy of synthesis and generalization by P. Ricoeur (2002) can be hardly overestimated, since hermeneutics becomes, on the one hand, his way of philosophical reflection of the problem of understanding, and on the other hand, an instrument for the development of philosophical reflection itself. (Sivak, 2013; Sivak 2019)

In our review, the next stage of hermeneutics development is particularly important, which is associated with the emergence of cognitive hermeneutics, moving the focus from the ontology of understanding to its epistemological aspects projected to the ability to create, re-create and convey the meaning of the language of the texts read in a competent communicative discourse, to a certain extent distracted from the subjective characteristics of the exercise of the understanding process and emphasizing the role played by the logical-and-epistemological axioms, imperatives and conventions in the understanding. In this regard, interesting are the ideas of H.G. Gadamer (1985), who undertook to present the regulations of hermeneutic research behavior, its subject, method and ways of analyzing the results. Gadamer's thesis important for our consideration is the thesis stating that hermeneutical thinking is the reader's conversation with text and a search for truth exercised jointly with its author (Gadamer, 1985). Despite the complexity of the rational, thesis-based presentation of 
the entire palette of Gadamer's views, they quite clearly manifest the idea that the interpretation of the language of the text is its "reading from the strongest point, mediating the strengthening of the truth contained in it." Thus hermeneutic "conversation with the text" is possible only when "transfer and proof" by the author of his/her thoughts take place — it means that the logical-and-epistemological component is important in the structure of the hermeneutic analysis. The lack of clear presentation of the latter in pedagogy, as mentioned in the introduction, makes the topic under discussion relevant. (Komel, 2014)

However, the methodological analytical palette presented reveals another important problem in the scope of our consideration: the idea of a rigid demarcation between religious and scientific traditions in the interpretation and construing of the meanings of pedagogical texts presented to society is increasingly recognized as unproductive. This is confirmed by the conclusions of such authors as A.A. Nuno (2014), Del Nero (2015), E.B. Taylor (2015), P. Ceccarelli and Lindenmeyer (2012), who pointed at a significant degree of similarity of the interpretative tools applied within the framework of the religious-and-theological hermeneutic tradition as well as in the matrix of scholarly humanitarian culture standards.

The lack of linguistic and stylistic structure of pedagogy, which complicates the process of interpretation of the content and meaning of texts by the community of readers, is pointed out by many modern authors of methodological and scientific works, which is noted in the works of P.A. Alexander (2017), B.J. Barczynski and R.M. Kalina (2015), M.B. Magolda (2004), W. Brezinka (2012). Today, as before, some domestic and foreign books and magazines provide a wide range of opinions about the attribution of pedagogical knowledge entirely to the field of Arts and Humanities and the inexpediency of its construction in the humanitarian logical-andepistemological form. Such opinions are substantiated in detail by the authors of domestic and foreign philosophical and scientific works (Anderson, 1961; Bauer, 1988; Brezinka, 2012; Billig \& Waterman, 2014; Shirish, 2013). As a consequence, the authors arrive at the conclusion that there is no sense for pedagogy as a field of knowledge, presented in numerous texts, to seek to fit in a correct stylistic norm of a scientific product, instead it is enough to limit itself to the literary norms of journalistic genre; this collective opinion inevitably includes the attribution of the religious theological tradition in pedagogy to the Arts and Humanities content as mentioned in the title of the article. However, the analysis of other scientific sources proves the assumption that even in the humanities, belonging to the "weak epistemological version", one or another theoretical form should be reflected, which would have not only logical content, but also stylistic normative encoding (Shirish, 2013; Koskinen, 2018; Pritchard, 2013; Lundie, 2015; Shepperd, 2016). The analysis of the sources shows that even today a number of traditional logical-andepistemological structures in pedagogical cognition are manifested with varying degrees of accuracy (Leś, 2017; Wettersten, 1987; Kornienko, 2015; Mallaband et al., 2017). The need to find a way to present the science of the education patterns as a theory, properly observing the laws of epistemology and logic, is clearly indicated in the works of such authors as A.A. Kornienko (2015), B.J. Barczyński and R.M. Kalina (2015), B. Mallaband et al. (2017). Many relevant ideas of such aspect are presented in other sources; thus, attempts to identify methodological status of comparative pedagogical research are made in the work of C.A. Anderson (1961); the methodology of the development and implementation of design and innovation activities in education is discussed by S.H. Billig and A.S. Waterman (2014), while J. Wettersten (1987) discusses the interdisciplinary nature of pedagogical knowledge and the coupling of methods of pedagogy as a science, related sciences' methods and methods of describing educational reality used in non-scientific forms of knowledge and religious-and-theological practices, while a similar topic of the general

XLinguae, Volume 13 Issue 3, June 2020, ISSN 1337-8384, ISSN 2453-711X 
methodological segment of scientific pedagogy and the option to include theological, religious-and-mystical and esoteric forms of knowledge therein is presented in the work of T.S. Shirish (2013); the idea of theoretical standardization of pedagogy is proclaimed and justified by N.J. Bauer (1988); the possibilities of using philosophical conclusions in the educational system is studied by W. Brezinka (2012), where the author particularly focuses on the content of the philosophy of religion in the pedagogical space. Russian authors (Korzhuev et al., 2018a; Korzhuev et al. 2018b; 6; Korzhuev et al., 2017) point to the need to address the topic of correlation of objective pedagogical reality and subject-and-scientific reality when studying education (Korzhuev et al., 2018a; Korzhuev et al. 2018b; 6; Korzhuev et al., 2017), and such consideration inevitably includes the correlation of the concept of "reality" in the conventional humanitarian pedagogy and religious-and-theological tradition. The need to extrapolate the logical-and-epistemological discourse of pedagogical studies into the context of hermeneutics and psychology of understanding discussed above is indicated by the authors of the work (Korzhuev et al., 2017).

Notwithstanding a very representative list of scientific sources associated with reflections on the methodological status of pedagogy, many of the solutions and outcomes are only outlined, and the problem of understanding the scientific-andtheoretical (and, in particular, logic-and-epistemological) horizons of pedagogical knowledge and search of a possibility of a correct and appropriate, in terms of a rational proportion, combination of traditional science and the Arts and Humanities, including theology and religion that are part of the conceptual landscape of modern pedagogy and thus require methodological reflection, cannot be considered satisfactorily resolved. This idea is confirmed by the findings of the authors of works devoted to the methodological reflection on pedagogical knowledge, including such authors as M.B Magolda (2004), G. Gardiner (2015), H.J. Koskinen (2018), D. Pritchard (2013), D. Lundie (2015). These studies contain a common idea that, in the modern context, the critical discourse in the area of the development of pedagogical knowledge, which has the right to claim to be part of the scientific field and can become a useful tool in the hands of professionals of practical education, continues to be relevant.

Several more works can be included in the relevant scientific segment mentioned above with a certain degree of accuracy. In particular, Tomasz Les (2017) in the work notes the specific nature of the theory of education developed by the scientific pedagogical community, its pivotal difference from the theories of another profile, and also brings the reader's attention to the philosophical and ethical aspects of such a theory as well as indicates the intentions standardizing and regulating the construction of such a theoretical form, without offering specific technologies for its creation, however. An interesting approach to the construction of the pedagogical theory is proposed by A.A. Hanan (2016), which is based on the ideas of pedagogy of dialogue, synthesizing reflexive social philosophy, liberalistic, pragmatic and aesthetic perspectives. However, even upon a superficial analysis, the synthesis of the three components mentioned above shows eclecticism in relation to the content and methods of constructing an educational theory, which would be logically and epistemologically correct and include segments that cannot be attributed to the traditional science. Finally, the work of J. Shepperd (2016) presents an attempt to reduce pedagogical research to a comparison of the phenomena of what was expected and actually achieved in pedagogical practice in the process of introducing various educational innovations, limiting this research to the phenomenological level, without considering the idea of constructing the logic of pedagogy, which we cannot agree with.

In view of the above works of philosophers of science, methodologists, representatives of philosophy of religion, and education professionals, we believe it makes sense to put forward the assumption that the problem of theoretical as well as 
logical-and-epistemological formatting of educational research is inevitably associated with the problem of stylistic representation of all epistemological attributes of pedagogical knowledge and search. This segment is very scarcely addressed today in methodological and specific pedagogical studies. To confirm this conclusion, we could use the scientific dialogue of such methodologists as N. Snaza (2018) and H. Letiche (2017). The very title of the article by (Snaza, 2018), proclaiming the scientific pedagogical topic and approach to its exploration, and that of the article published as a response from the opponent (Letiche, 2017), indicate unfavorable situation in the construing of a scientific and textual "portrait" of pedagogy: they are translated into Russian as "puzzling pedagogy" (the first adjective also can be translated as "difficult to understand...", "confusing with its intricacy pedagogy") in the work of $\mathrm{H}$. Letiche and as "pedagogy discredited from the scientific point of view..." and "full of many coincidences" in the case of N. Snaza. The problematic nature of the scientific status of pedagogy and its textual presentation is confirmed by other extracts from the works of the two polemists. On the one hand, they emphasize the specificity of the object of pedagogy, its striking difference from the objects of mathematics and natural sciences and the resulting impossibility to build a pedagogical theory following the pattern of the STEM subjects; on the other hand, there is an urgent need for systematization of a huge array of empirical data, ideas, approaches, concepts, theoretical structures, accumulated from practical education, as well as knowledge penetrating into pedagogy from areas that traditionally do not have a scientific status. All this mediates the problem of correct display of pedagogical knowledge in scientific texts, since "confusing pedagogy, which surprises with a lack of structure in it" (Snaza, 2018; Letiche, 2017), in turn, produces texts that are difficult to interpret by readers.

All this brings us to the conclusion suggesting the relevance of studying the two following aspects: a) what is the degree of separation of stylistic pedagogy as a science from pedagogy as a humanitarian sphere, which includes a segment of religious and theological knowledge, which has been actively penetrating into the landscape of the study of educational problems in recent times; b) what is the degree of similarity of interpretation of humanitarian texts of traditional scientific pedagogy and religion-oriented texts, and what are the arguments supporting this similarity? This can be briefly displayed by the question, to what extent the scientific pedagogy of construing and interpretation of the text content can be combined with religious tradition and in what areas pedagogy is incompatible with non-scientific religious forms of knowledge and its interpretation.

\section{Results}

The philosophical and methodological critical reflection of modern pedagogical texts in terms of unambiguity of the reader's interpretation of linguistic structures widely used by the authors demonstrates the need to combine hermeneutics with a set of logical-and-epistemological tools. Taking into account the thesis of the hermeneutical philosopher G. Frege (2000) that truth consists in the correspondence of "a picture with what it depicts", here are some fragments of pedagogical texts of traditional and religious orientation and the discussion on the ways of their semantic and logical-andepistemological "interpretation".

The number one thesis, which we would like to support using examples of interpretation of religious texts, is the thesis of similarity, i.e. essential similarity of hermeneutic perspectives of text analysis and interpretation of their meanings in religious and conventional pedagogical scientific traditions. For example, researchers studying the problems of construing meanings of the Holy Scripture (Shulga, 2017) admit the existence of the Bible commentaries differing among themselves as quite natural. In particular, using the analogy method, interpreters of religious status have

\footnotetext{
XLinguae, Volume 13 Issue 3, June 2020, ISSN 1337-8384, ISSN 2453-711X
} 
the right to use their own language and rely on their own experience of world perception and its stylistic reflection. For example, one of the episodes of the Old Testament interpretation, "When Moses came down from Mount Sinai with the two tablets of the covenant law in his hands, when he came down from the mountain, he was not aware that his face was radiant with rays because he had spoken with the Lord" (Shulga, 2017). Not very proficient in the ancient Greek language, St. Jerome interpreted the word "rays" as "horns", picking one of the meanings of the ancient Greek original. At the same time, it is quite illustrative that the perception of Moses with horns on his head was "reproduced" in the famous sculpture of Michelangelo.

The presence of literal meaning in a religious work does not mean that figurative language shall be excluded from the set of interpretative and construing tools. For example, the interpretation of the parable of wheat and tares: "Listen! A sower went out to sow. And as he sowed, some seeds fell on the path, and the birds came and ate them up. Other seeds fell on rocky ground, where they did not have much soil, and they sprang up quickly, since they had no depth of soil. But when the sun rose, they were scorched; and since they had no root, they withered away. Other seeds fell among thorns, and the thorns grew up and choked them. Other seeds fell on good soil and brought forth grain, some thirtyfold, some sixtyfold, and some hundredfold" (Shulga, 2017). The Parable of the Sower, from which a passage has been quoted, ends with an allegorical interpretation coming out of the mouth of Jesus answering the question of the apostles about the meaning of the parable's text: "When anyone hears the word of the kingdom and does not understand it, the evil one comes and snatches away what is sown in the heart; this is what was sown on the path. As for what was sown on rocky ground, this is the one who hears the word and immediately receives it with joy; yet such a person has no root, but endures only for a while, and when trouble or persecution arises on account of the word, that person immediately falls away. As for what was sown among thorns, this is the one who hears the word, but the cares of the world and the lure of wealth choke the word, and it yields nothing. But as for what was sown on good soil, this is the one who hears the word and understands it, who indeed bears fruit and yields, in one case a hundredfold, in another sixty, and in another thirty" (Blomberg, 2005). Jesus attaches spiritual allegories to every element of the parable, so the sower symbolizes God, the seed is the symbol of God's word, different types of soil, on which a grain or a seed falls, correspond to psychological types of people, who are oriented towards different values, birds are the embodiment of Satan, and thorns are the allegory of the hardships of earthly life. Above we see an allegorical way of interpretation, which distinguishes the explicated meanings of the figures present in the text from the common verbally perceived meaning of each individual figure of the text (in this case, each word).

The content of interpretation and construing acceptable in religious tradition includes such components as "plot" and "allegory". Thus, the famous Parable of the Prodigal Son illustrates the drama of a Jewish father who managed to forgive his son, and a number of allegories are constructed again: the prodigal son appears as a sinner, the father is a symbol of God, and the son runs away from God; ultimately, the hardhearted Pharisee is embodied by the figure of the elder brother. Clement of Alexandria offers his interpretive version of the parable, where the father's gift to his son (the ring) symbolizes the baptismal ceremony, the feast - the Last Supper, the clothes that the son puts on upon returning home symbolize immortality, and the shoes (sandals) are a reference to the journey to heaven (Blomberg, 2005). The important thing here is the moral lesson conveyed through a set of allegorical tools.

All the examples above and a lot of similar ones enable us to state that the religious tools of interpreting and construing texts are partially similar to scientific and pedagogical tools. However, the traditional interpretative tools inevitably immerse the text in the logical-and-epistemological framework and initiate various attitudes of the reader, while the tools of religious interpretation priori "crystallize" the position of 
concordance with the source and its author, where criticism is possible only in the format of deviation, for example, from the Christian doctrine. In particular, the Council of Nicaea harshly criticized the way of interpreting the idea of creation by the Arians, and the Fifth Ecumenical Council set standards of correct interpretation of the meaning of a number of prophecies, sharply criticizing the interpretative lines of Theodore of Mopsuestia. In connection with the idea of the interpretative canon indisputability, various religious interpretative traditions have such clichés as "the text, whose meaning is set canonically", "the primacy and authority of patristic interpretation", "the analogy of faith" and a number of others that dramatically restrict the scope of interpretations and ways to construe. The authority of the "Patriarchs" in this case is indisputable, as they have exceptional holiness and unbated zeal for the observance of truth. The "analogy of faith" is reflected in Augustine's aphoristic thesis "I believe so that I may understand; I understand so that I may believe", and therefore the interpreter (exegete) shall not make any statements contradicting the doctrine and must reveal both full and incomplete meanings of the Scripture, yet supplementing the "canon" only with a clear and complete doctrine of the Church.

In the last paragraph, we actually came close to the distinction between religious and scientific traditions of interpretation of texts. The latter, as already noted above, in the case of even "modest" attempts to "translate" the allegorical content of the text to the reader, inevitably gets involved in the formulation of judgements, often of a critical nature, triggering a scientific dialogue on a wide range of topics. Here we shall note that the recipient's appeal to modern logical-and-epistemological ideas and their reflection in the content associated with humanitarian pedagogical knowledge and methods of obtaining thereof often shows the impossibility of interpreting their content that would be adequate to the meanings assumed by the author. This leads to the need for methodological-and-pedagogical detalization of consistent interpretative discourse and is explained through the thesis that the interpretation of the text content should not have any contradictions, and if "two fragments contradict each other, then we should look for a third fragment, which would somehow reconcile them and enable us to proceed to discussion discourse of interpretation" (Frege, 2000).

The above-mentioned discussion of the discursive nature in the pedagogical analysis of texts is somewhat similar to the above-described interpretation of texts in the religious tradition and appeals to attempts to reveal to the reader the specific contents of the pedagogy-oriented terms, categories, metaphors, synecdoche, metonymy and other special stylistic means of expression that are used quite often in pedagogical texts. Linguists call this situation "contextual certainty". For example, the use of the metaphor "red ribbons" in science and education" in the pedagogical text is addressed to the historical analogy: in the XVI century, such ribbons were used to tie important state documents, and in modern educational community, this metaphor is used to briefly denote the bureaucratization of education and its "fouling" with various regulatory documents hindering teachers from performing their direct duties. Commonly used in pedagogy, the "flipped classroom" cliché as a metaphor decoded by the interpreter of the text assumes the change of traditional roles (a teacher, who teaches, and a student or a pupil, who is taught) in the educational process: here the student acquires knowledge and skills independently, demonstrating the results to the teacher, and the latter is a reflective subject in relation to the student's results, a consultant, who directs the learning route.

Of course, particular difficulties in identifying all of the above arise in the cases when the mentioned context is structurally complex, heterogeneous and cannot be reduced to one semantic segment, therefore education, viewed as a social institution, simultaneously may well be viewed as a service. In this case, the synthetic logicaland-hermeneutic analysis of the text is a complexly structured, a priori unpredictable activity of the reader, which involves logical reflection on text elements, resorting to

XLinguae, Volume 13 Issue 3, June 2020, ISSN 1337-8384, ISSN 2453-711X 
dictionaries and encyclopedic sources, revealing of the meaningful ties between various fragments, an attempt to expand or to reduce the author's description or reasoning, compression of a text fragment, an attempt to express the thought stans pede in uno or clarify the semantic field of a term proposed by the author.

The considered interpretive procedures of scientific pedagogy, appealing to the revealing of the contextual certainty of text figures, fall within the scope of similarities between scientific and religious traditions, however, this is basically the only similarity. The researcher belonging to scientific pedagogy, as a rule, projects the analysis of the text onto the logical-and-epistemological field, since in pedagogical texts the authors themselves rarely resort to reasoning as a functional-and-semantic type of speech, which assumes the substantiation of the proposed theses using a set of arguments. Such arguments could include an analysis of whether the set of features explaining a phenomenon that is described in the article meets the criterion of completeness of the shared set, as well as various combinations of empirical, theoretical and contextual substantiations. The theoretical substantiation includes, in particular, the logical substantiation, for example, references to the logical principles of identity, contradiction, excluded middle, and sufficient reason. Thus, the stylistic designation of the identity of pedagogical objects and phenomena is very difficult and, in most cases, appeals to the "softer" forms such as "similarity and difference" that are also reflected by the authors of pedagogical texts in a very confusing manner. For example, such two semantically similar concepts (though this similarity is almost never stylistically denoted) are research studies and problematic based learning. In fact, the similarity of the phenomena that are denoted in a different way is very significant, since both involve the activity of the student aimed to understand the problematic situation, the transition to a clear formulation of the educational problem and action to resolve it.

Stylistic designation of observance of the logical law of sufficient reason by the authors of pedagogical texts, which is almost completely absent in the religious interpretive tradition and inherent in the tradition of scientific pedagogy, appeals, in particular, to the following list: a) upon studying a sample from $\mathrm{N}$ students we have come to a conclusion...; b) based on the facts or findings presented in the ... sources (list), we can make quite a fair conclusion...(conclusion); c) based on the theoretical law widely accepted in psychology ... the author's pedagogical conclusion ... seems well substantiated d) the conclusion derived is supported by the reference to the works of ... (a certain pedagogical authority). Certainly, in the text of the research work, the given stylistic clichés of logical-and-epistemological status shall be supplemented with the linguistic reflection of extra-logical tools, displaying thoughtful contemplation of the reader of the text a) on the extent, to which we may consider representative the test sample, on the basis of which the conclusion was made; b) on the extent, to which the investigated problem is covered in the entire range of scientific sources considered by the author; c) whether it is correct to attribute the psychological regularity, to which the author appeals, to the pedagogical field considered in the text; and d) whether it is correct to appeal to the opinion of ... (certain authority) in respect of a ...(certain question). The entire list mentioned above illustrates the insufficiency of solely used logical-and-epistemological "reading" of the text pedagogical knowledge, at least, because the degree of similarity and difference of objects and phenomena of education and the degree of sufficiency of arguments in favor of a certain substantiation of the proposed conclusion for a quantitatively unmarked object field is determined with significant error, inevitably resorting to intuition inherent in hermeneutic vision of the text.

The synthesis of hermeneutic "reading" and the logical-and-epistemological analysis of language of a pedagogical text (the conversation of a reader with the author, according to Gadamer) discussed above, their relationship and convergence that pertain to scientific pedagogy and are virtually refused by the religious tradition 
assume consideration of stylistic clichés in the status of critical reflection of the meaning and logic of the narrative by the reader of the text, which can be illustrated using the following examples:

- reading the text, in which the characteristics of research studies and problematic based learning are described separately, one can hardly escape thinking about their kinship;

- reading the author's text, one cannot but agree with the statement that the technology of learning described has obvious valuable advantages, however, even "shallow" reading reveals a number of its shortcomings as well;

- the author of the text read, of course, could not be unaware of ..., however, for some reason, he does not mention it in his reasoning.

The presented clichés can be also supplemented by a number of reviewer's judgmental text forms, since through the read text one can "recognize" cultural symbols of the pedagogical field of the described epoch. For example, coming across the name of M. Knowles in a scientific test on pedagogy, the reader gets motivated to find other works of this author and reveals the tectonic shift that accompanied the changes in interpretation of the learning process during the transition from an industrial to a postindustrial phase of social development - this shift is denoted by the cliché of "learning through life" and is manifested through the person's self-identification as a learner having a deep intrinsic motivation for self-development throughout life;

— through the explication of the emotional background, meaning and hidden motives of the expressive means of the author's text the reader becomes aware of the value of pedagogical knowledge and methods used to obtain it represented through the author's language - this is illustrated by the following forms: a) apparently, without realizing it, the author semantically formalizes ... in a completely different way than it was done by earlier authors, highlighting such features that have not been previously reflected in pedagogical publications; b) the fact that the author considers... (some historically recorded technology of learning) exclusively as a defect is very upsetting; - the stylistics of the pedagogical text read and the degree of the author's effort to involve the reader in a dialogue trigger the understanding of the author's image in the text by the reader, the author's scientific and textual portrait, and the degree of interest in the fact that the author's position, expressed and substantiated, would be adequate to the intention as well as accepted and understood by the reader - stylistically this may be demonstrated, for example, as follows: a) let me take you on a little journey into the history of the interpretation of the ideas of personality-oriented approach in pedagogy; b) let's think together (ask ourselves), if it is really an univocal idea that the proposed innovative technology is absolutely necessary for modern education.

The methods of substantiation in religious traditions are significantly different from the traditional scientific methods considered above. While neither the author of a scientific text on pedagogy nor the reader are immune today from a plenty of errors of scientific interpretation, the Catholic commentator, for example, is exposed to errors much less than the teacher conducting research, since the former deals with texts that were quite clearly defined by the Church at the Council of Trent, and much of this is presented implicitly. The number of canonical regulations is relatively small, and it is very unlikely that the interpreter who has carefully read them would make errors (here we can add that the Vatican Council has defined the range of texts intended for direct understanding, almost memorizing). Pope Leo XIII in the Encyclical Providentissimus Deus defined the maxims concerning the authorship of the Fathers - the Encyclical declared the unconditional authority of the Holy Fathers in the interpretation of any text of the Bible as a collection of truths in the field of faith and morality. Therefore, these canons of faith and morality are designated as a guide for the interpretation of texts; any condemnation and criticism of the positions of the Fathers are prohibited. The principle of analogy of faith mentioned above (I believe so that I may understand;

XLinguae, Volume 13 Issue 3, June 2020, ISSN 1337-8384, ISSN 2453-711X 
I understand so that I may believe) is regarded by the Church as a strict interpretative and construing adherence to Catholic doctrine, since the Lord himself is the author of the Holy Scriptures and doctrines binding on the Church.

Therefore, in the religious tradition, the interpretative field of the text is mainly educationally-orientated, performing the function of broadcasting the content of canonical documents to believers in a language which is clear to them and using images (and symbols) they are familiar with, and of course, the function of introducing to the faith of those who have certain faith-fearing intentions. The logical content of interpretation and construing in the religious tradition is also very narrow - the logical references used in scientific pedagogy are limited to deductive forms: if I believe, I admit a priori the maxims broadcasted by the adherents of the doctrine and exclude any doubt about them, showing to the opponents of the faith only the dogmas of the doctrine, without allowing to doubt their truth (I do not recognize the thesis that "social-and-cultural practice is the criterion of the truth of the doctrine"); if I fail to fulfill the requirements of the doctrine, I undertake the whole responsibility for the consequences upon myself, reflect on my deviation from the laws and moral codes of the doctrine, and seek to correct these deviations. In the religious and scientific traditions of interpretation, appeals to authorities also differ significantly: in religious interpretation, authority is an indisputable imperative, while in scientific and pedagogical interpretation, authority is comprehensively studied by the researcher in terms of the substantial correctness of statements, their logical transparency and appeal to modern times (the obsolescence of the authority's statements and their dissonance with the transformed social order and cultural realities can be recognized as quite legitimate as well). (Frederick, 2015)

All what has been just presented above explains quite well the narrowness of the stylistic reflection of interpretation and construing in the religious tradition, since in scientific pedagogy, logical stylistics is much richer, as well as the stylistics of meaningful justification, which is confirmed by the clichés of pedagogical judgmental and reflective analytics given as examples in the text above. This is substantiated by the fact that the "canons" themselves, i.e. the initial postulative foundations of scientific pedagogy, are not formulated in a sufficiently clear and rational manner, are exposed to the influence of time and transformations of the social request to a much greater degree than the foundations of doctrine, and interpreted polyphonically even at the theoretical level. Naturally, in the religious tradition of interpretation and construing of texts, the judgmental and critical content is extremely poor.

The narrative presented in this part of the article provides a platform to summarize the research result derived:

- given all the difference of positions of adherents who founded religious hermeneutics and those detaching themselves from religious-and-theological aspects, the modern level of development of humanitarian knowledge and its "epistemologically weak" pedagogical version cannot be deeply comprehended with the use of logical-and-epistemological tools alone. The analysis of the pedagogical text in the logic of traditional science shows a significant degree of similarity with the interpretation performed within the framework of religious tradition, which mediates the conclusion about the need for scientific pedagogy to adopt the experience of religious interpretation of texts, stylistically aesthetic use of metaphors, synecdoche, metonymy, periphrasis and other techniques to enhance the stylistic expressiveness of text figures;

- a significant difference in the interpretation and construing of texts in religious and scientific-and-pedagogical traditions is the degree of manifestation of critical reflexive statements (basically not expressed in the religious tradition, it is the essence of the researcher's existence in the scientific discourse);

- synthesis of hermeneutic and logical-and-epistemological analysis of the language of scientific pedagogical texts initiate the above-described critical reflection thereon 
that includes, along with the well-known logical-and-epistemological procedures, a multidimensional content analysis, the deep integration of the reader into a text portrait of the author and the explication of scientific and pedagogical image of the latter, as well as logical and meaningful continuation of the author's findings and interpretations, their supplement, clarification and compression; in the religious form of interpretation and construing, the "integration" mentioned above means the unequivocal unquestioned acceptance of the author, who is an adherent of the doctrine, as a reference model and the ideal of the worldview, the nature of the activity and social behavior;

— the thesis used in the philosophical hermeneutic school of H.G. Gadamer (1985)

that "hermeneutical thinking is the conversation of a reader with the text" is one of the methodological and substantive foundations of the formation of a scientific dialogue culture in the scientific and pedagogical community. This dialogue clarifies definitions of pedagogical concepts, specifies the logical framework of their interconnections, provides space for semantic compression and crystallization of meaningful forms of pedagogy, regulations and specific strategies for research in this area as well as the form of achieving research consent in the case where the initial positions of the dialogue participants are significantly different. In the religious tradition, this "conversation" actually comes down to the monologue of the doctrine's adherent, while "the listener" of such monologue acts as a subject, assimilating theistic knowledge transferred, who is ready, in turn, to transfer it in the course of its own social activities.

\section{Discussion}

The synthetic representation of the hermeneutic and logical-and-epistemological interpretation of the pedagogical text and the analysis of its language are a multi-genre component of the modern concept called critical pedagogy. Like textual products that belong to the genre of literary and theatrical criticism, "critical pedagogy" is, on the one hand, a layer of knowledge revealing the content, meanings and logic of fragments of works to the reader of texts that are not sufficiently spotlighted (or are not recognized) even by their authors, and on the other hand, it reveals the regulations and procedures of critical pedagogy itself as a segment of reflective, philosophically colored scientific knowledge.

One of the important meaningful aspects of critical pedagogy is the comparison, presented in the main body of the article, of such inherent - both in the scientific activity and in the religious tradition - forms as the interpretation and construing of the content of texts. These are both purely scientific texts, and religious texts focused on the segments of social life that are important from the pedagogical point of view, related to education, morality, categories of goodness, justice, humanity, etc. The comparative conclusions presented to the reader in the main body of the article that became the object of our reflection enabled us to make a meaningful addition concerning a number of specific aspects of hermeneutics of the religions that were left beyond the scope of our analysis. For example, these include the traditions of Buddhist hermeneutics, which developed independently of Western Europe's hermeneutics, and analyzing the former, we believe we can add a number of observations to what has been said above. They refer to the manifestation of a somewhat greater degree of closeness of Buddhist hermeneutics to such an interpretation of it, which is successfully used by humanitarian researchers. Given the complexity of the matter, the interpreted texts can be divided into literal (that need to be retold to the listener as accurately as possible) and those that need to be interpreted, requiring additional revealing of meanings on top of the content presented therein as well as decoding of the implications and hidden, not readily understandable nuances that reflect a deep understanding of the author's content. The analysis of the features

XLinguae, Volume 13 Issue 3, June 2020, ISSN 1337-8384, ISSN 2453-711X 
of Buddhist hermeneutics also reveals the difference between the unambiguous orientation towards the doctrine's adherent in the Western European tradition and the Buddhist principle of "orientation towards the adherents". In the Buddhist religious tradition, this principle implies orientation towards the personality of the text's author and the personality (type of personality) of the recipient. This, in particular, splits the personarium of interpreters into four types of Holy Fathers and four types of presentation of doctrines, focused on the level of initial preparedness of the listener, mediating one or another way of comprehending the meaning of the canon written. Unfortunately, we have not found any in-depth theological studies of Buddhist hermeneutics performed in the rational religious study format, so in this section of the article we present only the results of primary reflection, showing a slightly greater closeness of Buddhist maxims to the humanitarian hermeneutics of "scientific usage".

\section{Conclusion}

The presented narrative brings us to several conclusions:

- modern pedagogical knowledge, reflected in the text and positioning synthesis of science, art, religion and everyday practice as inevitable in the humanitarian concept of "pedagogy", assumes the transfer of this synthetic representation to the field of hermeneutic "reading" of texts, naturally combined with logical-and-epistemological analysis. At the same time, there is a similarity between the classical scholarly humanitarian tradition of interpretation of texts and the religious tradition, which is reflected in the importance of the subject's appeal to the original or secondary text as an object of the cultural field and an intellectual phenomenon, archiving the findings of science or religious conceptualism;

- the similarity between the scientific and religious traditions of interpretation mentioned above refers also to such forms of content interpretation as a) decoding and presentation of the semantics and stylistics of the text to the recipient's mind through a number of images and symbols that are clear to the recipient; b) decoding the essence of the metaphors, synecdoche, periphrasis and metonymy used by the author. The latter can be designated as a segment of experience, appropriate for adoption by scientific pedagogy from religious tradition;

- the essential difference between scientific interpretation and interpretation performed within a religious tradition is the degree of manifestation of the recipient's reflective position that demonstrates the ability to identify the correctness of the text correlation by the author: a) the degree, to which the principles of identity, contradiction, and sufficient reason are observed, and legitimacy and correctness of pedagogical generalizations, analogies and extrapolations, and b) recognition of a cultural icon of the era's pedagogical field, awareness of the value of pedagogical knowledge proposed in the text, manifestations of scientific and textual portrait of the author and evaluation of its contribution to pedagogy. At the same time, in the religious field, such manifestation is strongly restricted to the canon and the imperative form of its presentation; in the scientific pedagogical tradition, it is a component of activity immanently embedded in research practices.

\section{Bibliographic references}

ALEXANDER, P. A. 2017. Reflection and Reflexivity in Practice Versus in Theory: Challenges of Conceptualization, Complexity, and Competence. In: Educational Psychologist, vol. 25, n. 4, pp. 307-314. ISSN - Print 0046-1520.

ANDERSON, C. A. 1961. Methodology of comparative education. In: International Review of Education, vol. 7, pp. 1-23. ISSN: 0020-8566.

BARCZYNSKI, B. J. - KALINA, R. M. 2015. Science of Martial Arts - Example of the Dilemma in Classifying New Interdisciplinary Sciences in the Global Systems of the Science Evaluation and the Social Consequences of Courageous Decisions. In: Procedia Manufacturing, vol. 3, pp. 1203-1210. ISSN: 2351-9789 
BAUER, N. J. 1988. Foundational Studies as a New Liberal Art: Educology. Annual Convention American Educational Studies Association. URL: https://files.eric.ed.gov/fulltext/ED303446.pdf

BILLIG, S. H. - WATERMAN, A. S. 2014. Studying Service-Learning: Innovations in Education Research Methodology. London: Routledge. ISBN: 0-8058-4275-6

BLOMBERG, C. 2005. Interpreting the Parables. Moscow: Logos. ISBN-13: 978-08308-3967-4

BREZINKA, W. 2012. Philosophy of Educational Knowledge: An Introduction to the Foundations of Science of Education, Philosophy of Education and Practical Pedagogics. London: Springer Science \& Business Media. ISBN 978-94-011-2586-4

CECCARELLI, P. - LINDENMEYER, C. 2012. Avatars of magic thoughts. In: Cliniques Mediterraneennes, vol. 85, n. 1, pp.41-49. ISSN: 07627491

CONEY, C. L. 2014. Critical Thinking in its Contexts and in Itself. In: Educational Philosophy and Theory, vol. 47, n. 5, pp. 515-528. ISSN: 0013-1857

DAWES, G.W. 2004. Religion, Philosophy and Knowledge. Cham: Palgrave Macmillan. ISBN 978-3-319-43500-8

DEL NERO. V. 2015. Between magic and astrology in the Renaissance. In: Giornale Critico della Filisofia Italiana, vol. 94, n.3, pp. 648-657. ISSN: 0017-0089

FREDERICK, D. 2015. The contrast between dogmatic and critical arguments. In: Organon F, vol. 22, n. 1, pp. 9-20. ISSN 1335-0668.

FREGE, G. 2000. Logic and Logical Semantics. Collected Papers. Moscow: Aspect Press. ISBN: 5-7567-0128-1

GADAMER, H. G. 1985. Hermeneutyka a filozofia praktyczna. Studia Filosoficzne. Studia Filosoficzne, n, 1, pp. 21 - 22. ISSN 0039-3142

GARDINER G. 2015. Teleologies and the Methodology of Epistemology. Epistemic Evaluation: Purposeful Epistemology. Oxford: Oxford University Press. ISBN: 9780199642632

GRASSI, M. 2017. The Loving Creativity of Law. An Essay on Paul Ricœur's Hermeneutical Ethics. In: Filozofia, vol. 72, no 3, pp. 204-214. ISSN 0046-385X

HANAN, A. A. 2016. What is critical about critical pedagogy? Conflicting conceptions of criticism in the curriculum. In: Educational Philosophy and Theory, vol. 50, n. 10, pp. 903-916. ISSN: 0013-1857

HEIDEGGER, M. 1993. Introduction to "What is Metaphysics?". Moscow: Respublika. ISBN 5-250-01496-8

KORNIENKO, A. A. 2015. The Concept of Knowledge Society in the Ontology of Modern Society. In: Procedia - Social and Behavioral Sciences, vol. 166, pp. 378386. ISSN: 1877-0428

KORZHUEV, A. V. - IKRENNIKOVA, Y. B. - NIKITINA, E. K. - RYAZANOVA, E. L. 2018. Philosophical and methodological reflection of educational theory as a phenomenon of scientology. In: Novosibirsk State Pedagogical University Bulletin, n. 2, pp.103-118. ISSN 2658-6762

KORZHUEV, A. V. - MADZHUGA, A. G. - KISLYAKOV, P. A. - AMIROF, A. F. - SOKOLOVA, A. S. - IKRENNIKOVA, Yu. B. 2017. Semantic content of Pedagogic Knowledge and Problem of Comprehension. In: Ponte, n. 10, pp. 274-280. ISSN: 0032-423X

KORZHUEV, A. V. - IKRENNIKOVA, Y. B. - NIKITINA, E. K. - RYAZANOVA, E.L. 2018. Theoretical standard of pedagogical knowledge: Correct scientific and problem description of educational reality, hypothesis and results of the study. In: Novosibirsk State Pedagogical University Bulletin, n. 5, pp. 108-126. ISSN 26586762

KOSKINEN, H. J. 2018. Antecedent Recognition: Some Problematic Educational Implications of the Very Notion. In: Journal of Philosophy of Education, vol. 52, pp. 178-190. ISSN 0309-8249

XLinguae, Volume 13 Issue 3, June 2020, ISSN 1337-8384, ISSN 2453-711X 
LETICHE, H. Bewildering pedagogy. In: Journal of Curriculum and Pedagogy, vol. 14, pp. 236-255. ISSN: 15505170

LUNDIE, D. 2015. The Givenness of the Human Learning Experience and its Incompatibility with Informational Analytics. In: Educational Philosophy and Theory, vol. 49, n. 4, pp. 391-404. ISSN: 0013-1857

MAGOLDA, M. B. 2004. Evolution of a Constructivist Conceptualization of Epistemological Reflection. In: Educational Psychologist, vol. 39, pp. 31-42. ISSN 0046-1520.

MALLABAND, B. - WOOD, G. - BUCHANAN, K. - STADDON, S. - MOGLES, N. M. - GABE-THOMAS, E. 2017. The reality of cross-disciplinary energy research in the United Kingdom: A social science perspective. In: Energy Research \& Social Science, vol. 25, pp. 9-18. ISSN: 2214-6296

NUNO, A. A. 2014. Sympathetic magic and magic-religious mentality from Antiquity to the modern world: a long-lasting mental structure? In: Dialogues d'Histoire Ancienne, vol. 40, n. 1, pp. 147-162. ISSN: 07557256

PRITCHARD, D. 2013. Epistemic Virtue and the Epistemology of Education. In: Journal of Philosophy of Education, vol. 47, n. 2, pp. 236-247. ISSN 0309-8249

RICOEUR, P. 2002. The Conflict of Interpretations. Moscow: Riker. ISBN 5-86090054-6

SHEPPERD, J. 2016. Heidegger on Transforming the Circumspect Activity of Spatial Thought. In: Educational Philosophy and Theory, vol. 48, n. 8, pp. 752-763. ISSN: 1469-5812

SHIRISH, T. S. 2013. Research Methodology in Education. Morrisville: Lulu Publication. ISBN 9781312093744

SHULGA, E. N. 2017. The man and the time in the Hermeneutic Tradition. In: Chelovek, vol. 5, pp. 144 - 153. ISSN 0236-2007

SIVAK, J. 2013. Paul Ricœur: A Methodologist of History. With regard to his Time and Narration. In: Filozofia, vol. 68, n 9, pp. 752-765. ISSN 0046-385X.

SIVAK, J. 2019. Heidegger and the Question of Existence of Phenomenology. In: Filozofia, vol. 74, n. 6, pp. 485-500. ISSN 0046-385X.

SNAZA, N. 2018. Aleatory entanglements: (Post) humanism, hospitality and attunement - A response to Hugo Letiche. In: Journal of Curriculum and Pedagogy, vol. 14, pp. 256-272. ISSN: 15505170

TAYLOR, E. B. 2015. Primitive Culture. Researches into the Development of Mythology, Philosophy, Religion, Art, and Custom. London: Murray. ISBN: 978-14400-5381-8

TOMASZ LES. 2017. The research potential of educational theory: On the specific characteristics of the issues of education. In: Educational Philosophy and Theory, vol. 49, n. 14, pp. 1428-1440. ISSN: 0013-1857

WETTERSTEN, J. 1987. On the unification of psychology, methodology, and pedagogy: Selz, Popper, and Agassi. In: Kluwer Academic Publishers, vol. 18, n. 4, pp. 1-14. ISSN: 1573-3254

Words: 9375

Characters: 62637 (34,80 standard pages)

Prof. Andrey V. Korzhuev

Department of Medical and Biological Physics

I.M. Sechenov First Moscow State Medical University (Sechenov University)

8 Trubetskaya Street,

119991, Moscow

Russia

akorjuev@mail.ru 
Prof. Tatiana Vlasova

Department of Theory and Methods of Professional Education

Don State Technical University

1 Gagarin Square

344000, Rostov-on-Don

Russia

tvlasova@rambler.ru

Prof. Vladimir Sinyachkin

Department of Russian Language and Intercultural Communication

Peoples' Friendship University of Russia (RUDN University)

6 Miklukho-Maklay Street,

6117198, Moscow

Russia

sinyachkin-vp@rudn.ru

Assoc. Prof. Vladimir V. Vorozhikhin

Library Center named after Academician L.I. Abalkin

Plekhanov Russian University of Economics

36 Stremyannyi Pereulok

115093, Moscow

Russia

vorozhikhin@mail.ru

Assoc. Prof. Natalia E. Sudakova

1) Institute of Pedagogy, Psychology and Philosophy of Education

Moscow Academy of Professional Competencies

29/33 Nizhegorodskaya Street, bldg. 15

109052, Moscow

Russia

2) UNESCO Department

Russian Presidential Academy of National Economy and Public Administration

84 Prospect Vernadskogo, bldg 2

119571, Moscow

Russia

sovetnik.imtp@mail.ru 